\title{
Article
}

\section{On Genre as Social Action, Uptake, and Modest Grand Theory}

\author{
Sune Auken \\ University of Copenhagen
}

Carolyn Miller's (1984) "Genre as Social Action," the primary topic—or target—of Anne Freadman's brilliant and thought-provoking article, holds a special place in genre research. If I pick up an unknown piece of research on genre, the first thing I do is look for Miller's article in the bibliography. If it is not there, the text in my hand will probably be of little of value to my work for lack of orientation. Moreover, as Freadman (2012) notes, convention in genre research suggests that when you mention the article, it is in good form to add a positive qualifier. It will often be framed as having "formative influence" (MacNeil, 2012), as a "landmark essay" (Feinberg, 2015), or as "seminal" (Andersen, 2008; Devitt, 2009a; Motta-Roth \& Herbele, 2015; Møller, 2018; Paré, 2014; Tachino, 2012), "groundbreaking" (Bawarshi, 2000; Smart, 2003; Winsor, 2000), or "oft-cited" (Devitt, 2009b). More than just paying lip service to the greats in the field, adding this qualifier demonstrates that the author knows her way around Rhetorical Genre Studies and is mindful of Miller's central place within it. This status as a classic text is in itself an example of the bidirectionality of uptake that holds a central place in Freadman's work. "Genre as Social Action" could not be canonical when it was first published. A canon had to form, and the article's central place within it had to be recognized by later researchers, before Miller's text could be taken as oft-cited, seminal, or groundbreaking.

Seen from within the field, Freadman herself is something of a force of nature. During the last 10 to 15 years, her conceptualization of the role of uptake in genre (Freadman, 1987/1994, 2002) has become one of the kingpins of genre research. However, her reflections are not an attempt to put down the competition; the questions at stake are very real, and the arguments put forth touch upon the fundamentals of genre research. I will not presume to adjudicate between Miller and Freadman; if nothing else, that would be an immediate invitation to further academic litigation and thus of very little value as an attempt to settle the issues at hand. Instead, I shall try to locate the significance of Freadman's reflections within genre research now and in the years ahead. 
Volume 30, 2020

http://journals.sfu.ca/cjsdw

A point of terminology. Freadman (2020) establishes an enlightening distinction between genre studies (research that uses genre in empirical research of case data) and genre theory (research that analyzes the concepts and issues at play in genre or in genre studies). To these, I add the overarching term genre research to designate the unity of the two as they pertain to the understanding of genre. Even though Freadman's study moves broadly within the realm of Rhetorical Genre Studies, any of the three terms-genre studies, genre theory, or genre research-can, with one caveat, be applied to either of the other two "traditions" (Hyon, 1996) of genre research; or to any other research approach that endeavors to take up genre as a systematic research topic. The caveat is mostly a matter of habit: genre studies usually appears in the context of Rhetorical Genre Studies, whereas researchers in the English for Specific Purposes tradition, following Swales (1990) and Bhatia (1993), tend to refer to their approach as genre analysis. Moreover, the three traditions already meet and interact frequently, as witnessed by, for instance, Devitt (2015) and Thieme (2019).

I also add a slightly polemical extension to the terminology of genre research: genre research proper. I use this to refer to the research, studies and theory, which works on genre or genrerelated problems in the knowledge that genre research exists as an organized field. As previously indicated, genre is studied in many contexts without this knowledge. By consequence, researchers can proclaim as new discoveries about genre that are old as the hills in genre research proper, or they can make actual discoveries in genre without impacting genre research proper-simply because they don't know about it.

The distinction between genre research and genre research proper is obviously one of reciprocal genre difference; the likeness makes the difference relevant. If, extending Freadman (2020), we take works of genre research as a genre; then the difference between genre research and the sub-category genre research proper is definitely a difference of genre as well. As such, it is most notably a difference of uptake and audience. Works of genre research proper systematically take up previous works of genre research proper and, in turn, attempt to secure uptakes from later work within genre research proper. Beyond that, a research paper may seek to secure uptakes from other quarters-including from a broader field of genre research-and may get uptakes from an even wider variety of contexts. Uptakes are not exclusive.

Freadman (2020) identifies two aspects of Miller's (1984) account of genre as social action that subsequent research has focused on: the view of genre as "a rhetorical means for mediating private intention and social exigence (Miller, 1984, p. 163)" and exigence itself as an objectified social need that defines the rhetorical (social) situations in which genres act (Freadman, 2020, p. 105). These are indeed fundamental effects of Miller's work. I shall, however, venture the claim that there are four even more radical consequences of Miller's article-or, more precisely, of its 
Volume 30, 2020

http://journals.sfu.ca/cjsdw

reception (uptake!): a change of research field; a change of topic; a shift in the most basic understanding of what genre is; and, as a result of these first three changes, the stabilization of genre research as a field. All are present at full force in Freadman's reflections.

Research field. There were brilliant linguistic and rhetorical studies in genre prior to Miller's foundational article; Jamieson's brilliant 1975 study "Antecedent Genre as Rhetorical Constraint" springs to mind, but many others exist. However, the most important studies in previous decades were from the hands of aesthetic researchers, in particular literary scholars like Jolles (1958), Frye (1968), Jauss (1982), Todorov (1990), Genette (1992), and Fowler (1982). (As the question at hand is partially one of chronology, it is fitting to remark that most of those studies were written earlier than the edition referenced above; thus, Jolles (1930), Frye (1957), Jauss (1968), Todorov (1978), and Genette (1979).) Also, of course, there is Derrida (1980) and the "Law of Genre" that Freadman herself takes up.

This predominance of literary scholars working on genre changed in the aftermath of Miller; in particular, after another landmark work, Freedman and Medway's 1994 anthology, Genre and the New Rhetoric, which, among other important works, includes the second printing of both "Genre as Social Action" and Freadman's first article on uptake, "Anyone for Tennis." Since then, genre research proper has become a matter for rhetoric, linguistics, composition studies, information studies, and several other fields, but aesthetic fields are only marginally represented. This is not because anybody has been kept out, but because a separate and highly organized research field has been built on the foundation that Miller's study laid. In the process, the previous literary studies receded to the background, although Miller herself returned to Fowler's book in 2017. The only literary scholar to be widely represented in genre research proper is, unsurprisingly, the deeply interdisciplinary Bakhtin (notably, his 1986 "The Problem of Speech Genres"), who also plays a major role in Freadman's reflections.

Topic. The change in research field goes hand in hand with a basic change of topic. Miller repeatedly states that her aim is to make room in genre research for what she calls "modest" or "de facto" genres; these are the genres of everyday discourse. She posits her ambition as one of making room in the study of genre for these genres alongside the study of literature and high oratory, but the actual uptake of her work is more dramatic. In contemporary genre research, genres in use have become the main topic (Sunesen, 2015, p. 100), with only a marginal representation of high oratory and literature (Auken, 2015).

Understanding of genre. With the change of topic also comes a change in the fundamental understanding of what genres are. Miller (1984), careful not to overstate her case, talks about the way a "rhetorically sound [emphasis added]" (p. 151) definition of genre would have to organize 
Volume 30, 2020

http://journals.sfu.ca/cjsdw

genres by the actions they are used to perform-by their social role. However, the uptake of Miller's article has been much more assertive; unsurprisingly, one might say, as it established a full research field. Contemporary genre research sees genres as recurrent forms of social action, defined by their function and use. Again, Miller is less radical than her uptake; this is no longer just a heuristic assumption or a way to approach the topic from a specific field. It is a claim about the character-or, if you will, even nature-of genre.

These three changes in genre research add up to a fourth: a stabilizing of genre research as an organized, dialogic field. What I have called genre research proper came to be through the uptake of Miller's article and other foundational work. Something was indeed founded. Impressive as previous studies in genre were, they did not constitute a fully formed research field in genre, but were largely either individual efforts, or efforts springing from other research fields, most notably literary studies. It could be said that Miller and her uptakers (my apologies for the neologism) created a particular group of agents: people specializing in the study of genre, or "genre researchers" (Paré \& Roy, 2002, p. 33). In the last 25 years these genre researchers have had the opportunity to work together-developing concepts, discussing analyses and practical applications, and driving an advanced interchange between genre studies and genre theory. Thus, a number of distinctions originally made in analyses of concrete genre use, such as "genre set" (Devitt, 1991) and "genre system" (Bazerman, 1994), have since made it into genre theory, and from there back into other new studies of concrete genre use.

Furthermore, by locating genre as something that plays a role at the centre of human interaction and not just as a specialized tool in literature and the arts, Miller and the researchers walking the trail she blazed have also secured a much wider field of relevance for genre research. Thus, it may be true, as Freadman (2020) remarks, that rhetorical genre theory has limited stability, a short future, and a modest ambition (pp. 107-108). However, it must be noted that the near omnipresence of genre in human interaction ensures that its modest ambition is to be a mild, subdued form of grand theory. In the words of Ashley Rose Kelly (2017):

Attending to conversations across disciplines and national contexts will become increasingly important as genre continues its unabated tour of our scholarly homes. Understanding genre studies is then to understand an interdisciplinary conversation that propels this idea of genre toward a complicated and likely contested idea of human communication in all its linguistic, social and cognitive capacities. (p. 293)

In the spirit of Freadman, it must be noted that genre as a research concept moves because of human agency. Individual agents find genre a useful concept and take it up in new research contexts; but in so doing, they have definitely given genre an unabated tour. The same can to an extent be said of Freadman's own concept, uptake, which has appeared in discussions of topics as diverse 
Volume 30, 2020

http://journals.sfu.ca/cjsdw

as women's suffrage (Thieme, 2006), health information campaigns (Emmons, 2009), nineteenthcentury advice literature (Regaignon, 2015), jury deliberations (Devitt, 2016), and the debate over anthropogenic climate change (Auken \& Sunesen, 2020). In each, uptake has proven immensely useful. This, however, also makes it challenging to maintain a consistent assumption of modesty in genre theory.

If you take Miller's influence in this very expansive sense, it is obviously true when Freadman (2020) says of her essay "I accept broadly the framework of Rhetorical Genre Studies" (p. 105) because her reflections have their pertinence from this framework.

Freadman's (2020) essay raises two major points: the choice between subject and agent as the term for the person who acts through genre, and the discussion of the character, significance, and understanding of the concept of exigence. Of these, the first is, as she rightly notes, to some extent a standoff with herself, as she used the term subject with significant force in her 2014 article "Where is the Subject? Rhetorical Genre Theory and the Question of the Writer." However, it is worth noting that the change in terminology also carries a central move of said article one crucial step further. A recurring thread in Freadman's work, made explicit in the 2014 article, is the role of uptake-and by consequence the role of the individual agent-in genre, defying the assumption that genres can somehow do things on their own without the active effort of the agent. This move, placing the genre user (whatever term you use for her) at the core of genre as social action, emphasizes the original rhetorical interests of Miller's genre theory. Replacing subject with agent takes this move one step further.

Freadman's second point, the question of the character, role, or-if you will-place of exigence, poses more properly a challenge to Miller; albeit still, as per above, within the broader framework of Rhetorical Genre Studies. The challenge cuts to the core of Miller's study because the relocation of exigence from the individual (Bitzer, 1968) to the generic situation helps Miller establish genres as sites of social action. Freadman's reply, however, is not a simple relocation of exigence back to the individual or local situation-although she does relocate it-because it still leaves the question of the genres as sites of social action unresolved.

Freadman's solution, or suggestion, is to think of genres as something much less fixed than an overarching social purpose, and to see the place and use of genre as a question of jurisdictions: genres get their place in the world through their use in local, more-or-less regulated spheres of human activity. She freely admits that her usage of the term jurisdiction is metaphorical, but like many good metaphors, it hits a central rhetorical concern. Moreover, it is in immediate contact with crucial texts in genre research, such as Devitt (1991, 2004, 2009a), Reiff and Bawarshi (2016), and Schryer (1993). It also aligns well with Freadman's own previous work.

Freadman herself explicitly connects her idea of jurisdictions with the four "different ways 
Volume 30, 2020

http://journals.sfu.ca/cjsdw

that genres emerge and evolve within their communities" (Miller, 2017, p. 23) that Miller describes in her 2017 chapter "Where do Genres Come from." However, it also fits into a larger ongoing debate within genre research. Genres do not exist in isolation, but form larger patterns including other genres (Auken, 2018). They also connect in time, as evidenced by Freadman's own discussion of uptake and by Swales's (2004) discussion of genre chains (2004). Many different concepts have been brought into play to describe these relationships, on top of the aforementioned genre set and genre system: at least, both genre repertoire (Orlikowski \& Yates, 1994) and genre ecology (Spinuzzi \& Zachry, 2000) have been used, and a broader sweep through existing genre research would undoubtedly unearth many more related terms and descriptions. The idea of jurisdictions as the place of genre cuts across these different distinctions between genre patterns and as such can be used to interrogate each.

I here pick a simple example: the relationship between the genre set and the genre system. The genre set, as defined by Devitt (1991), "reflects the professional and social relations" (p. 339) of a given group - in Devitt's case, tax accountants. Bazerman (1994) adds the concept genre system (the definition of which is notably not identical to Freadman's use of the term in her essay) to describe the interaction of multiple genre sets in a larger multi-person activity. Thus, within university life, the students have one genre set, the professors another, and the different administrators, support staff, and leaders have other ones still. The sum of these genre sets forms the university's genre system.

If we interrogate these genre patterns as jurisdictions, several questions become pertinent. Given that the genre system contains the genre sets, what then is the relationship between their jurisdictions? To what extent does the jurisdiction of the system override the jurisdiction of the sets? Moreover, do the sets on some point hold enough independence to stand against the concerns of the system? What happens with jurisdiction at the borders of the different sets? How does the individual set respectively the genre system relate to other jurisdictions? Moreover, what roles do the uptakes of individual agents play in the dynamic between set and system?

I shall not hazard a reply to these questions. They multiply and get even more complex if we look at them closer, and we have not even begun to study actual data or activate other related concepts-like the categorization from Miller's 2017 essay. However, these questions demonstrate the central place of Freadman's reflections in genre research.

Instead, I will return to a previous point: the overall impact of Miller's study on the topic, research field, and understanding of genre in genre research. If genre is, in fact, a fully formed research topic, then it must be possible to see a rhetorical approach to genre as one valid approach to genre among several, and not as the only valid approach to genre. This, not incidentally, is in 
Volume 30, 2020

http://journals.sfu.ca/cjsdw

accordance with Miller's cautious approach as per above. As genre is a constant of human communication and cognition, it can and should be studied by linguistics, psychology, aesthetics, history, sociology, political science, communication, and a wide array of other fields. Many of these fields already have excellent prerequisites for contributing to genre research. And, in fact, most already have local, but important, studies connected to genre research proper, and all have a plethora of researchers actually working with genres, even though they do not conceive of their work as genre research. Therefore, the unabated tour of genre research can continue for a long time.

Blazing a trail is also leaving others to walk it in their own way. Miller and her uptakers formed genre research proper as a fundamentally rhetorical endeavor, and this cannot and should not be undone. However, when new research fields with different methodologies and different research needs take on genre, the understanding of genre, too, needs to adapt. Rhetorical genre research, having established the field and moved it a very long way, could work actively to create a research space for other approaches, without losing anything. In fact, this would expand the reach and impact of the rhetorical insights that made genre a proper research topic.

Thus, the question arises. What role would Freadman's reflections play if we see genre as an independent topic of research and not "just" as a sub-topic of rhetoric? Freadman's reflections, and both her central notes to Miller, centre on the specifically rhetorical character of genre.

The question of who acts in genre, the subject or the agent, is worth seeing for what it is: a technical question. Indeed, it is precisely the technicality of the question that spells out its role in any analysis of genre. As genre is taken up in new research contexts, the name given to the genre user will shift with each new context. In the arts alone, she can be the "author," "writer," "painter," "director," "playwright," “actor," "composer," "performer," or a number of other names. In other fields, the agent can be a group, an NGO, a government, a "think-tank," an "agent" (again, but in a different meaning; in fact, several possible meanings). Each of these names will be meaningful in their own research context, and each-and its role in individual uptakes and genre uses-will have to be analyzed on its own terms. None of them is fully replaceable by Freadman's term agent. However, neither can they fully replace it. In fact, the question of genre use as agency is likely to come up in a number of transformed versions, each depending on the research assumptions at work in each field.

Which brings us, of course, to the question of jurisdictions. As genre research moves into new fields, it will need to engage with new-and often deeply ingrained and many-layered-genre jurisdictions at play in those fields. There is no overarching jurisdiction; there is no "genre constitution." Therefore, when the study of genre moves into new fields, the regulations at play change; and so does the way these regulations are used or manipulated by individual agents. 
Volume 30, 2020

http://journals.sfu.ca/cjsdw

These changes will influence the way we analyze the genres and the uses of genres in the different fields. Thus, the change of research field will-obviously-affect the choice of topic, and this will, in turn, affect the theoretical understanding of what genre is, and what genre does. As the regulations change with each new jurisdiction, so does the way genre performs as a research concept in its new place. This will make room for understandings of genre that add to and modify the rhetorical conception of genre prevalent in current genre research.

Genre research is at once a modest venture and an adventure in grand theory. Freadman is right to posit genre as a research concept that is self-reflective, limited, and in constant transition. It can play a key role in numerous research contexts and throw a surprising new light on them all, while keeping them connected. Therefore, one might speculate that the true power of genre research is its ability to establish a discipline-based interdisciplinarity, binding together research fields as it moves between them.

\section{References}

Andersen, J. (2008). The concept of genre in information studies. Annual Review of Information Science and Technology, 42(1), 339-367. doi:10.1002/aris.2008.1440420115

Auken, S. (2015). Utterance and function in genre studies: A literary perspective. In J. Andersen (Ed.), Genre theory in information studies (Studies in information, Vol. 11, pp. 155-178).

Bingley, UK: Emerald Group.

Auken, S. (2018). Understanding genre. Journal of Zhejiang International Studies University, 3(2), $14-27$.

Auken, S., \& Sunesen, C. (Eds.). (2020). Genre in the climate debate. Berlin, Germany: De Gruyter. Bakhtin, M. M. (1986). The problem of speech genres (V. W. McGee, Trans.). In C. Emerson \& M. Holquist (Eds.), Speech genres and other late essays (pp. 60-102). Austin: University of Texas Press.

Bawarshi, A. (2000). The genre function. College English, 62(3), 335-360. doi:10.2307/378935

Bazerman, C. (1994). Systems of genres and the enactment of social intentions. In A. Freedman \& P. Medway (Eds.), Genre and the new rhetoric (pp. 79-101). London, UK: Taylor \& Francis. Bhatia, V. K. (1993). Analysing genre: Language use in professional settings. London, UK: Longman.

Bitzer, L. F. (1968). The rhetorical situation. Philosophy and Rhetoric, 1, 1-14.

Derrida, J. (1980). The law of genre (A. Ronell, Trans.). Critical Inquiry, 7(1), 55-81.

Devitt, A. J. (1991). Intertextuality in tax accounting: Generic, referential, and functional. In C. Bazerman \& J. Paradis (Eds.), Textual dynamics of the professions: Historical and 
Volume 30, 2020

http://journals.sfu.ca/cjsdw

contemporary studies of writing in professional communities (pp. 336-355). Madison:

University of Wisconsin Press. Retrieved from

https://wac.colostate.edu/docs/books/textual_dynamics/chapter14.pdf

Devitt, A. J. (2004). Writing genres. Carbondale, IL: Southern Illinois University Press.

Devitt, A. J. (2009a). Re-fusing form in genre study. In J. Giltrow \& D. Stein (Eds.), Genres in the Internet: Issues in the theory of genre (pp. 27-48). Philadelphia, PA: John Benjamins.

Devitt, A. J. (2009b). Teaching critical genre awareness. In C. Bazerman, A. Bonini, \& D.

Figueiredo (Eds.), Genre in a changing world (pp. 337-351). Fort Collins, CO: The WAC

Clearinghouse. Retrieved from https://wac.colostate.edu/docs/books/genre/chapter17.pdf

Devitt, A. J. (2015). Genre performances: John Swales' Genre Analysis and rhetorical-linguistic genre studies. Journal of English for Academic Purposes, 19, 44-51.

doi:10.1016/j.jeap.2015.05.008

Devitt, A. J. (2016). Uncovering occluded publics: Untangling public, personal, and technical spheres in jury deliberations. In M. J. Reiff \& A. Bawarshi (Eds.), Genre and the performance of publics (pp. 139-156). doi:10.7330/9781607324430.c007

Emmons, K. K. (2009). Uptake and the biomedical subject. In C. Bazerman, A. Bonini, \& D. Figueiredo (Eds.), Genre in a changing world (pp. 134-157). Fort Collins, CO: The WAC Clearinghouse. Retrieved from https://wac.colostate.edu/docs/books/genre/chapter7.pdf

Feinberg, M. (2015). Genres without writers: Information systems and distributed authorship. In J. Andersen (Ed.), Genre theory in information studies (Studies in information, Vol. 11, pp. 43-66). Bingley, UK: Emerald Group.

Fowler, A. (1982). Kinds of literature: An introduction to the theory of genres and modes. Oxford UK: Oxford University Press.

Freadman, A. (1994). Anyone for tennis? In A. Freedman \& P. Medway (Eds.), Genre and the new rhetoric (pp. 43-66). London, UK: Taylor \& Francis. (Reprinted from The place of genre in learning: Recent debates, pp. 91-124, by I. Reid, Ed., 1987, Geelong, Australia: Centre for Studies in Literary Education, Deakin University)

Freadman, A. (2002). Uptake. In R. Coe, L. Lingard, \& T. Teslenko (Eds.), The rhetoric and ideology of genre: Strategies for stability and change (pp. 39-53). Cresskill, NJ: Hampton Press.

Freadman, A. (2012). The traps and trappings of genre theory. Applied Linguistics, 33(5), 544563. doi:10.1093/applin/ams050

Freadman, A. (2014). Where is the subject? Rhetorical genre theory and the question of the writer. Journal of Academic Language and Learning, 8(3), A1-A11. 
Volume 30, 2020

http://journals.sfu.ca/cjsdw

Freadman, A. (2020). A tardy uptake. Canadian Journal for Studies in Discourse and Writing/Rédactologie, 30, 105-132. doi: 10.31468/cjsdwr.781

Freedman, A., \& Medway, P. (Eds.). (1994). Genre and the new rhetoric. London, UK: Taylor \& Francis.

Frye, N. (1968). Anatomy of criticism. New York, NY: Atheneum Books.

Genette, G. (1992). The architext: An introduction (J. E. Lewin, Trans.). Berkeley: University of California Press.

Hyon, S. (1996). Genre in three traditions: Implications for ESL. TESOL Quarterly, 30(4), 693722. doi: $10.2307 / 3587930$

Jamieson, K. M. (1975). Antecedent genre as rhetorical constraint. Quarterly Journal of Speech, 61(4), 406-415. doi:10.1080/00335637509383303

Jauss, H. R. (1982). Theory of genres and medieval literature (T. Bahti, Trans.). In Toward an aesthetic of reception (pp. 76-109). Brighton, UK: The Harvester Press.

Jolles, A. (1958). Einfache Formen. Darmstadt, Deutschland: Wissenschaftliche Buchgesellschaft.

Kelly A. R. (2017). Postscript: Futures for genre studies. In C. Miller \& A. R. Kelly (Eds.), Emerging genres in new media environments (pp. 291-295). Cham, Switzerland: Palgrave Macmillan. doi:10.1007/978-3-319-40295-6_16

MacNeil, H. (2012). What finding aids do: Archival description as rhetorical genre in traditional and web-based environments. Archival Science, 12(4), 485-500. doi:10.1007/s10502-0129175-4

Miller, C. R. (1984). Genre as social action. Quarterly Journal of Speech, 70(2), 151-167. doi:10.1080/00335638409383686

Miller, C. R. (2017). “Where do genres come from?”. In C. Miller \& A. R. Kelly (Eds.), Emerging genres in new media environments (pp. 1-34). Cham, Switzerland: Palgrave Macmillan. doi:10.1007/978-3-319-40295-6_1

Møller, M. (2018). Running for fun, elected for real: A genre based analysis of two comedians' humorous election campaigns (Doctoral thesis, University of Copenhagen, Denmark).

Motta-Roth, D., \& Herbele, V. M. (2015). A short cartography of genre studies in Brazil. Journal of English for Academic Purposes, 19, 22-31.

Orlikowski, W. J., \& Yates, J. (1994). Genre repertoire: The structuring of communicative practices in organizations. Administrative Science Quarterly, 39(4), 541-574. doi:10.2307/2393771

Paré, A. (2014). Rhetorical genre theory and academic literacy. Journal of Academic Language \& Learning, 8(1), A83-A94. 
Volume 30, 2020

http://journals.sfu.ca/cjsdw

Paré, A., \& Roy, R. (2002). The Evolution of an Education Journal: A Genre Study. Canadian Journal for Studies in Discourse and Writing/Rédactologie, 17(2), 31-54. doi:10.31468/cjsdwr.486

Regaignon, D. R. (2015). Anxious uptakes: Nineteenth-century advice literature as a rhetorical genre. College English, 78(2), 139-161.

Reiff, M. J., \& Bawarshi, A. (Eds.). (2016). Genre and the performance of publics. Logan: Utah State University Press.

Schryer, C. F. (1993). Records as genre. Written Communication, 10(2), 200-234. doi:10.1177/0741088393010002003

Smart, G. (2003). A central bank's "communications strategy": The interplay of activity, discourse genres, and technology in a time of organizational change. In C. Bazerman \& D. R. Russell (Eds.), Writing selves/writing societies: Research from activity perspectives (pp. 9-61). Fort Collins, CO: The WAC Clearinghouse. Retrieved from https://wac.colostate.edu/docs/books/selves_societies/smart/smart.pdf

Spinuzzi, C., \& Zachry, M. (2000). Genre ecologies: An open-system approach to understanding and constructing documentation. Journal of Computer Documentation, 24(3), 169-181.

Sunesen, C. (2015). Genre and rhetoric. In S. Auken, P. S. Lauridsen, \& A. J. Rasmussen (Eds.), Genre and... (Copenhagen studies in genre 2, pp. 99-124). Copenhagen, Denmark: Ekbátana.

Swales, J. M. (1990). Genre analysis: English in academic and research settings. Cambridge, UK: Cambridge University Press.

Swales, J. M. (2004). Research genres: Explorations and applications. Cambridge, UK: Cambridge University Press.

Tachino, T. (2012). Theorizing uptake and knowledge mobilization: A case for intermediary genre. Written Communication, 29(4), 455-476. doi:10.1177/0741088312457908

Thieme, K. (2006). Uptake and genre: The Canadian reception of suffrage militancy. Women's Studies International Forum, 29(3), 279-288. doi:10.1016/j.wsif.2006.04.007

Thieme, K. (2019). Surface and depth: Metalanguage and professional development in Canadian writing studies. Canadian Journal for Studies in Discourse and Writing/Rédactologie, 29, 148159. doi:10.31468/cjsdwr.757

Todorov, T. (1990). Genres in discourse (C. Porter, Trans.). Cambridge, UK: Cambridge University Press.

Winsor, D. A. (2000). Ordering work: Blue-collar literacy and the political nature of genre. Written Communication, 17(2), 155-184. doi:10.1177/0741088300017002001 